\title{
The spermatozoa structure peculiarities of the subgenus Sumeriomys (Rodentia, Arvicolinae, Microtus)
}

\author{
Tanya A. Zorenko \& Fedor N. Golenishchev*
}

\begin{abstract}
Owing to distinct differences in size and shape in different taxa, spermatozoa can be of a high diagnostic value. The functional and evolutionary nature of such diversity is poorly understood. The purpose of the study was to summarize the data on the differences in sperm design and linear parameters between the subgenera Sumeriomys and Microtus (the genus Microtus) and to carry out the same comparison between the "socialis" and "guentheri" groups of species within the subgenus Sumeriomys. We obtained the data on shape and size of spermatozoa in seven nominal forms of the subgenus Sumeriomys. The species of the subgenus Sumeriomys are quite similar in sperm design, which distinctly differs from that in the representatives of the subgenus Microtus. The spermatozoa of the Sumeriomys species also differ from those of the Microtus representatives in some linear measurements and quantitative indices. These data confirm the taxonomic distinctness of the social voles as an independent subgenus Sumeriomys. Within the subgenus Sumeriomys some essential differences were revealed in sperm dimensions. The largest spermatozoa are observed in the species of the "guentheri" group, especially in M. guentheri (a head length $7.60 \mu \kappa)$. In $M$. hartingi they are slightly smaller in size (in two subspecies correspondingly 6.96 and 7.25 $\mathrm{mk}$ ). In three nominal forms of the "socialis" group the spermatozoa are smaller (a head length 7.01-7.21 $\mu \kappa)$, than in the "guentheri" group. The ratio of head length to its width in M. guentheri and M. hartingi is respectively 1.5 and 1.46, while in the "socialis" group, 1.42-1.47. In voles of the subgenus Microtus it is 1.8-2.4. The length of the medium part of spermatozoon's tail is the most variable character. The ratio of the sperm tail medium part length to head length in Microtus is higher than 2.8 (2.8-3.2), but in Sumeriomys it is lower than $2.8(2.4-2.7)$.
\end{abstract}

KEY WORDS: Microtus, Sumeriomys, spermatozoa, taxonomy.

Tanya A. Zorenko [zorenkot@lanet.lv], University of Latvia, Riga LV -1586, Krovald bulv. 4, Latvia; Fedor N. Golenishchev [f_gol@mail.ru], Zoological ibstitute, Russian Academy of Science, Universitetkaya nab. 1, Saint Petersburg 1999034, Russia.

\section{Особенности строения сперматозоидов у общественных полевок подрода Sumeriomys (Rodentia, Arvicolinae, Microtus)}

\section{Т.А. Зоренко, Ф.Н. Голенищев}

РЕЗЮМЕ. Сперматозоиды у представителей разных таксонов отличаются по форме и размерам и, поэтому, могут иметь большую диагностическую ценность. Причины и пути возникновения этого разнообразия не ясны. Цель работы — сравнить между собой морфологию и линейные размеры сперматозоидов у видов полевок подродов Sumeriomys и Microtus (род Microtus), а также сравнить в пределах подрода Sumeriomys две группы “socialis" и "guentheri”. Были получены данные по форме и размерам сперматозоидов у пяти номинальных форм подрода Sumeriomys. Форма сперматозоида сходна у всех изученных видов подрода Sumeriomys, но хорошо отличается от таковой полевок подрода Microtus. Между сперматозоидами представителей этих подродов также отмечены различия по линейным показателям и количественным индексам. Все это соответствует выделению общественных полевок в самостоятельный подрод Sumeriomys. Основные отличия были выявлены в размерах сперматозоидов. Наиболее крупные сперматозоиды обнаружены у видов группы “guentheri”, в особенности у M. guentheri (длина головки $7.60 \mu$ к). Несколько меньшие размеры отмечены у $M$. hartingi (соответственно у двух подвидов 6.96 и $7.25 \mu \kappa)$. У трех изученных видов группы “socialis" сперматозоиды по величине меньше (7.01-7.21 $\mu$ ), чем у представителей группы “guentheri”. Отношение длины головки к ее ширине у M. guentheri и у M. hartingi составляет соответственно 1.5 и 1.46, тогда как в группе "socialis" 1.42-1.47. У видов подрода Microtus этот показатель значительно больше 1.8-2.4. Длина срединной части хвоста сперматозоида - наиболее изменчивый признак. У общественных полевок она в 2.5-3.0 раза длиннее, чем головка сперматозоида. Отношение длины срединной части хвоста к длине головки сперматозоида у видов подрода Microtus больше 2.8 (2.8-3.2), в подроде Sumeriomys меньше - 2.8 (2.4-2.7).

КЛЮЧЕВЫЕ СЛОВА: Microtus, Sumeriomys, сперматозоиды, систематика. 


\section{Introduction}

Sperm cells are very diverse in size and shape among mammals (Cummins \& Woodall, 1985). Spermatozoon consists of head and tail. Sperm head includes nucleus that is covered by acrosome. In sperm tail four parts can be distinguished: connecting piece (neck), medium piece (midpiece), principal piece and end-piece (Fawcett, 1975). The tail gradually decreases in the diameter towards its end. Under the light microscope acrosome seems uniform. However, under the electronic microscope its complicated structure is noticeable (Bierła, 2006). It was shown, that the house mouse sperm head is divided into three modules (the acrosomal, postacrosomal and ventral spur module), which correspond to the main regions of the cytoskeletal mesh beneath the plasma membrane, i.e. the perinuclear theca (Medarde et al., 2013).

The hydrolytic enzymes in acrosome are necessary for penetration into an ovum contain. The most functionally important zone is a medium part of the tail, which provides energy for spermatozoon movement. Apparently, deficiency of ATP in mitochondrion (Baker et al., 2005; Zhabin et al., 2010) can be the cause of decreasing in mobility of gametes, which generally are settling down in an intermediate zone of a tail, a midpiece (Bierła, 2006). It is shown also that ability of spermatozoa in laboratory mice to way-ahead movements and fertilization is connected with energy release in glycolysis (Miki et al., 2004).

The sperm shape in voles tribe Arvicolini Kretzoi, 1955 is highly diverse. Aksenova (1978) distinguished three types of a head and acrosome shape of spermatozoa. In a number of species from different genera (Abramson \& Lissovsky, 2012): Microtus Schrank, 1798, Alexandromys Ognev, 1914 (A. fortis Büchner, 1889), Blanfordimys Argyropulo, 1933, Lasiopodomys Lataste, 1887 (L. (Stenocranius) gregalis Pallas, 1779), a sperm have a poleaxe head shape with a hook bent acrosome (type 1). In other species the head is oval, and acrosome represents a cone-shaped hillock, which lies in deepening of a body (type 2) or covers a body upwards (type 3 ). The second type is noted in some species of the genus Alexandromys (A. middendorfii Poljakov, 1881, A. maximowiczii Schrenk, 1859 and $A$. sachalinensis Vasin, 1955), whereas the third is found only in the representative of the subgenus Sumeriomys Argyropulo, 1933.

The spermatozoa from epididymis of social vole males, well differ in mobility. In social voles, mobile, vibrant, and motionless spermatozoa were found (Zorenko et al., 2005; Zorenko \& Motmillere, 2005). Vibrant spermatozoa fluctuate on one place only, without wayahead movements. A part of spermatozoa is not mobile. Quite often there is an adhesion of spermatozoan heads (aggregations); peculiar "asterisks" are formed as a result. In the sexually more active males aggregation of spermatozoa occurs later and more rarely. Thus, in a test-tube with physiological solution, $M$. s. socialis sperm mobility continues for several hours. The main function of vibrant sperm may be in formation of a copulatory plug (Zorenko, 2013).

Tendency to find a key to recognition of cryptic species in rodents, for a long time attracts attention of mammalogists to investigation of reproductive system, including spermatozoa structure (Meyer et al., 1972, 1996; Aksenova, 1978; Malygin, 1983; Cummins \& Woodall, 1985; Breed, 2004). The only representative of the subgenus Sumeriomys Argyropulo, 1933, whose accessory sex glands has been investigated is Microtus socialis nikolajevi Ognev, 1950 (Aksenova, 1973). The seminal vesicle (= vesicular glands) and prostate have been investigated in three species of the "socialis" group (M. socialis Pallas, 1773, M. paradoxus Ognev et Heptner, 1928 and M. schidlovskii Argyropulo, 1933) and in one species of the "guentheri" group: $M$. hartingi Barret-Hamilton, 1903 (Zorenko, 2013). Genitals of males and females of social voles are much better studied (Zorenko \& Aksenova, 1989; Zorenko, 2000). A shape and size of baculums are involved in the greatest attention of researchers, therefore this morphological treat has been investigated in many species of the subgenus (Simsek, 1981; Çolak et al., 1997; Zorenko, 2000; Golenishchev et al., 2002; Yiìit \& Çolak, 2002). There is not enough data on a sperm; however, quite often its shape and size distinctly differ between separate species (Aksenova, 1973). The analysis of $M$. socialis (Aksenova, 1978) showed that the shape of its spermatozoa head differed from all the other representatives of the tribe Arvicolini, and, in particular, from the species of the subgenus Microtus.

The purpose of the present study was to compare a shape and sizes of spermatozoa of five social voles species: M. socialis with two subspecies (M. s. socialis, M. s. nikolajevi), M. schidlovskii, M. paradoxus, $M$. guentheri Danford et Alston, 1880 and M. hartingi with two subspecies (M. h. strandzensis Markov, 1960 and M. h. lydius Blackler, 1916).

Opinions of the authors on taxonomic status of the Kopet Dag vole are different. The senior author considers it as an independent species, proving the opinion by data on the molecular and genetic analysis on a gene cytochrome $b$, partial sterility of hybrids from crossing of this form with Microtus socialis (Zykov \& Zagorodnyuk, 1988; Kryštufek et al., 2012; Zorenko, 2012) and morphology of body and brain (Zorenko, 2013). The junior author considers the Kopet Dag vole as a subspecies $M$. s. paradoxus. This opinion is based on data on experimental hybridization (F1 hybrids are fertile), a lack of karyotypic differences between their C- and Gbanded chromosomes (both subspecies have $2 n=62$ ), morphology (many features of the Kopet Dag vole have been found in some $M$. socialis subspecies) and molecular genetic analysis of a gene cyt $b$ (Golenishchev et al., 2003, Golenishchev \& Abramson, 2011; Golenishchev \& Malikov, 2011). M. paradoxus probably originated in the north of the Iranian Plateau. It could emerge in the result of the resettlement of some ancestral form from the West of the Middle East in the eastern direc- 
Table 1. Locality and number of males investigated in social voles (subgenus Sumeriomys).

\begin{tabular}{|l|c|}
\hline Taxon and locality & Number of males \\
\hline $\begin{array}{l}\text { M. socialis socialis } \\
\text { Russia, Kalmykia, Chernozemel'skiy District, Achineri }\end{array}$ & 3 \\
\hline $\begin{array}{l}\text { M. s. nikolajevi } \\
\text { Russia, Crimea, vicinity of Feodosiya }\end{array}$ & 3 \\
\hline $\begin{array}{l}\text { M. paradoxus } \\
\text { Turkmenistan, Central Kopet Dag, Dushak Mt. }\end{array}$ & 2 \\
\hline $\begin{array}{l}\text { M. schidlovskii } \\
\text { Armenia, Talin District }\end{array}$ & 1 \\
\hline $\begin{array}{l}\text { M. hartingi strandzensis } \\
\text { Bulgaria, Gramatikovo, type location }\end{array}$ & 2 \\
\hline $\begin{array}{l}\text { M. h. lydius } \\
\text { Turkey, Kirsehir }\end{array}$ & 2 \\
\hline $\begin{array}{l}\text { M.guentheri guentheri } \\
\text { Turkey, Kahramanmaras-Turkoglu }\end{array}$ & 2 \\
\hline
\end{tabular}

tion. Currently this nominal form is distributed in the Kopet Dag Mountains, the outskirts of the Iranian Plateau (Gvozdetskii \& Mikhailov, 1987). Two parts of distribution are known in Kopet Dag: central (Chuli Gorge, Haynelau Gorge, along the Firyuza River, near Kurkulab and Germab villages and on Dushak Mountain) and southern (on the banks of Sumbar and Chandyr rivers). Probably, $M$. paradoxus lives in northern Iran too. The range of this allopatric nominal form is small: 50 thousand $\mathrm{km}^{2}$ (Shenbrot \& Krasnov, 2005).

\section{Material and methods}

The animals were collected in different localities of the subgenus Sumeriomys distribution range and were kept in the laboratory of the University of Latvia in Riga and in the vivarium of the Zoological Institute of Russian Academy of Sciences in Saint Petersburg under standard laboratory conditions. The keeping of animals satisfied the requirements of Federation of European Laboratory Animal Science Associations (FELASA, certificate C-category). Animals were sacrificed by cervical dislocation, which is regarded as a humane method.

Localities and number of males investigated are shown in Tab. 1. The structure of a spermatozoon is shown on the scheme (Fig. 1). The spermatozoa were taken from a male epididymis, photographed at 1000x magnification using an Olympus BX51 microscope without preliminary processing. For measurement, spermatozoa were put onto slides in a drop of physiological solution, steamed and painted by the methylene blue. All samples were evaluated at $7 \times 40$ magnification. The following linear measurements were taken: the greatest head length and width, length of medium part and remaining spermatozoon tail. Besides, two indices were calculated - ratio of medium part length to head length of a spermatozoon, and ratio of head length to its width. For every nominal form of the social voles it was received from 30 to 60 measures. For every measurement, we calculated the arithmetic mean and its stan-

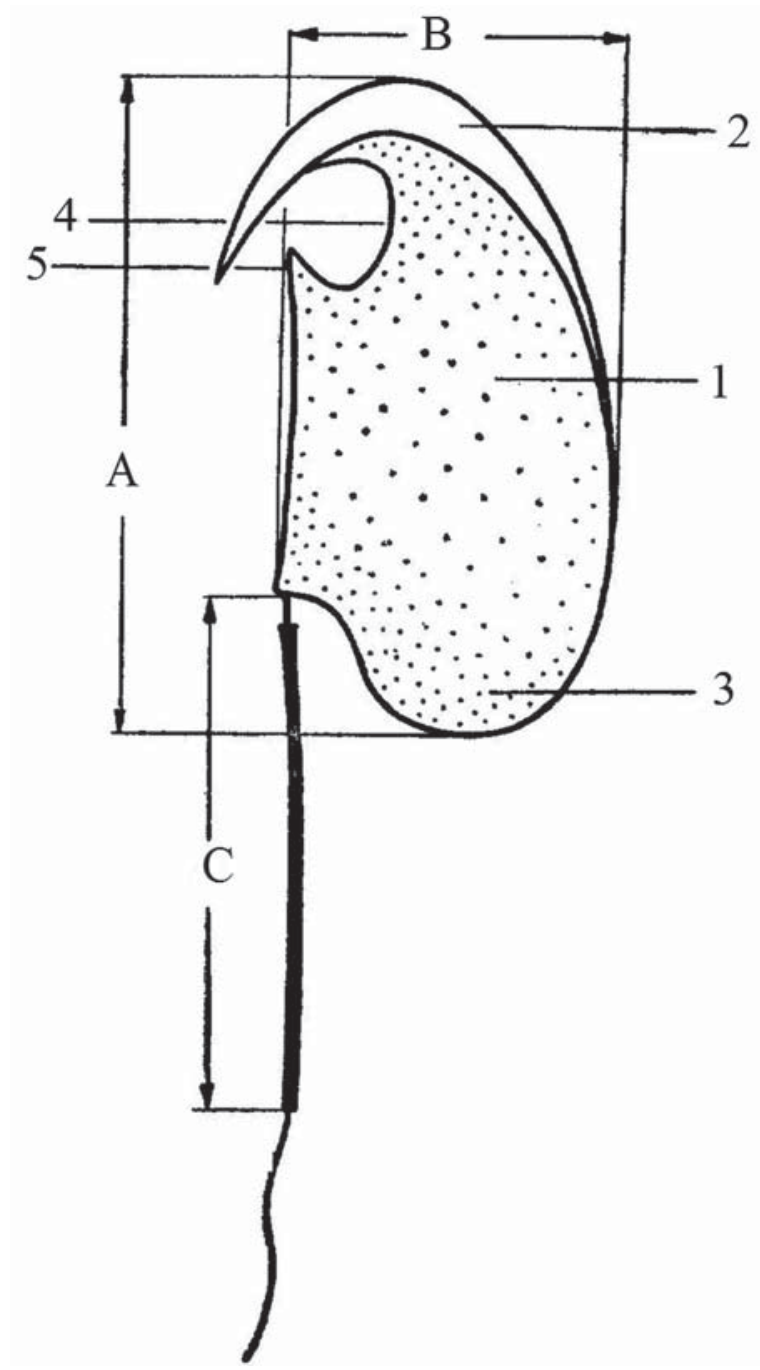

Figure 1. Scheme of a structure and dimensions of spermatozoa: 1 - nuclear, 2 - acrosome, 3 - ledge in back part of a head, 4 - dorsal pole, 5 - toothlike shoot, A - head length, B - head width, C - the length of medium part of a tail. 
Table 2. Sperm linear size. The arithmetic mean \pm standard error with limits in parenthesis are presented.

\begin{tabular}{|l|c|c|c|c|c|}
\hline Subspecies & $\mathrm{L}, \mu \mathrm{\kappa}$ & $\mathrm{D}, \mu \kappa$ & $\mathrm{L}$ midpiece, $\mu \kappa$ & $\mathrm{L} / \mathrm{D}$ & $\mathrm{L}$ midpiece / L \\
\hline M. g. guentheri & 7.60 & 5.09 & 19.33 & 1.5 & 2.55 \\
$n=30$ & \pm 0.08 & \pm 0.05 & \pm 0.19 & \pm 0.02 & \pm 0.03 \\
& $(7.0-9.1)$ & $(4.9-5.6)$ & $(16.8-21.6)$ & $(1.4-1.7)$ & $(2.3-3.0)$ \\
\hline M. . lydius & 6.98 & 4.70 & 17.65 & 1.46 & 2.54 \\
$n=40$ & \pm 0.09 & \pm 0.07 & \pm 0.16 & \pm 0.02 & \pm 0.04 \\
& $(7.0-8.2)$ & $(4.3-5.0)$ & $(16.8-19.2)$ & $(1.2-1.6)$ & $(2.1-3.0)$ \\
\hline M. h. strandzensis & 7.25 & 5.06 & 18.08 & 1.44 & 2.50 \\
$n=30$ & \pm 0.08 & \pm 0.10 & \pm 0.18 & \pm 0.02 & \pm 0.03 \\
& $(7.2-8.6)$ & $(4.8-5.3)$ & $(16.8-19.2)$ & $(1.1-1.6)$ & $(2.27-2.8)$ \\
\hline M. schidlovskii & 7.12 & 4.84 & 19.07 & 1.47 & 2.69 \\
$n=35$ & \pm 0.03 & \pm 0.02 & \pm 0.16 & \pm 0.02 & \pm 0.04 \\
& $(6.0-7.4)$ & $(4.8-5.0)$ & $(16.8-21.6)$ & $(1.3-1.6)$ & $(2.3-3.2)$ \\
\hline M. paradoxus & 7.21 & 4.97 & 17.28 & 1.46 & 2.40 \\
$n=60$ & \pm 0.06 & \pm 0.05 & \pm 0.17 & \pm 0.02 & \pm 0.03 \\
& $(6.0-7.9)$ & $(4.6-5.8)$ & $(16.8-20.4)$ & $(1.3-1.5)$ & $(1.9-2.9)$ \\
\hline \multirow{2}{*}{ M. s. socialis } & 7.15 & 5.06 & 17.96 & 1.42 & 2.51 \\
$n=60$ & \pm 0.05 & \pm 0.04 & \pm 0.19 & \pm 0.01 & \pm 0.03 \\
& $(6.2-7.4)$ & $(4.6-5.8)$ & $(14.0 \pm 19.2)$ & $(1.2-1.6)$ & $(2.0-3.2)$ \\
\hline \multirow{2}{*}{ M. s. nikolajevi } & 7.01 & 4.93 & 19.09 & 1.43 & 2.74 \\
$n=50$ & \pm 0.06 & \pm 0.05 & \pm 0.22 & \pm 0.02 & \pm 0.04 \\
& $(6.2-7.2)$ & $(4.3-6.0)$ & $(16.8-21.6)$ & $(1.1-1.5)$ & $(2.4-3.1)$ \\
\hline
\end{tabular}

Abbreviations: $n$ - number of specimens; L — head length; D — head width; L midpiece — the length of medium part of a tail; L / D — head length / head width ratio; L midpiece / L — length of medium part of a tail / head length ratio.

dard error. We compared arithmetic means by Student's t-test.

\section{Results}

The largest spermatozoa are characteristic for species of the "guentheri" group. Length of a head varies from 7.0 to $9.1 \mu \mathrm{K}$. The greatest head length was found in $M$. g. guentheri, though variability of this measurement is notable even in one male (Tab. 1). In the sister species, head length of $M$. h. lydius was smaller by $9 \%$ on the average $(p<0.001)$, and in $M . h$. strandzensis by $5 \%(p<0.05)$. Head length in $M . h$. strandzensis was distinctly bigger in comparison with $M$. $h$. lydius $(p<0.05)$. Width of a sperm head varies from 4.3 to 5.56 $\mu \kappa$. Its smallest width was recorded in $M$. $h$. lydius that distinguishes this form from $M$. h. strandzensis and $M$. g. guentheri $(p<0.001)$. Though the ratio of head length to its width $(\mathrm{L} / \mathrm{D})$ in individuals of this vole's group changes from 1.1 to 1.7 , species average values differed slightly (Tab. 2). Spermatozoa of social voles are shown on Figs 2, 3.

In three species of "socialis" group the head length of a spermatozoon is less in comparison with representatives of "guentheri" group, and varies from 6.0 to 7.9 $\mathrm{mk}$ (Tab. 2), reaching the greatest value in M. paradoxus. However, species of "socialis" group differ in this indicator: only head length of $M . s$. nikolajevi is much smaller, than M. paradoxus ( $p<0.01)$, while M. s. socialis and M. schidlovskii do not differ $(p<0.1)$.
Width of a spermatozoon, and also the ratio of its length to width in all investigated taxa of the "socialis" group are similar.

The length of the medium part of spermatozoon tail is variable. In species of "guentheri" group it is comparatively large part of tail, especially in $M . g$. guentheri (Tab. 2). It varies from 23.7 (strandzensis) to $25 \%$ (guentheri) of the total tail length. The medium part length of tail is 2.5 times bigger than head length of $M$. g. guentheri and two subspecies of $M$. hartingi $(p<0.01)$. Total length of a tail exceeds 10 times head length of a spermatozoon in these species. In species of "socialis" group the medium part of a tail is longer, than that in species of "guentheri" group, being 25-28\% of the total tail length, the longest - in M. schidlovskii and M. s. nikolajevi. The length of the medium part / the length of the head is similar (2.5-2.55) in "guentheri" species and more variable (2.4-2.74) in "socialis" group.

\section{Discussion}

In social voles the shape of a spermatozoon reminds a cockleshell snail as it was noted by Aksenova (1978). As a whole, specific differences in a sperm shape between species are insignificant; only the Kopet Dag vole has a back ledge of a head more rounded. For all that it may be connected with imperfections of method used. No consensus exists on a method to objectively assess size and shape of spermatozoa (Sánchez et al., 2013). On opinion of these authors the method of geo- 

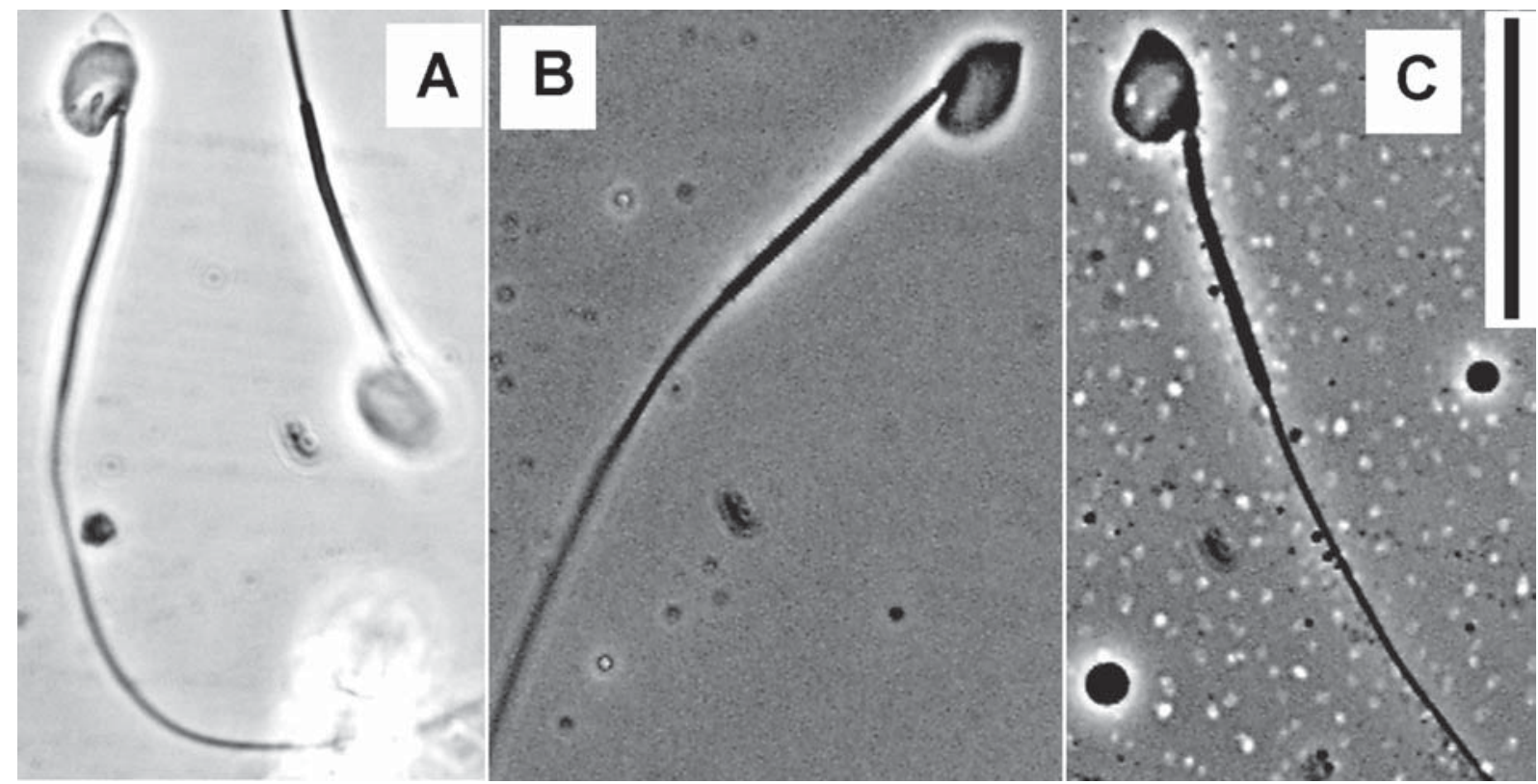

Figure 2. Spermatozoa of social voles of the "socialis" group: A - M. s. socialis, B - M. s. nikolajevi, C - M. paradoxus. The live spermatozoa. Scale bar $=20 \mathrm{~nm}$.

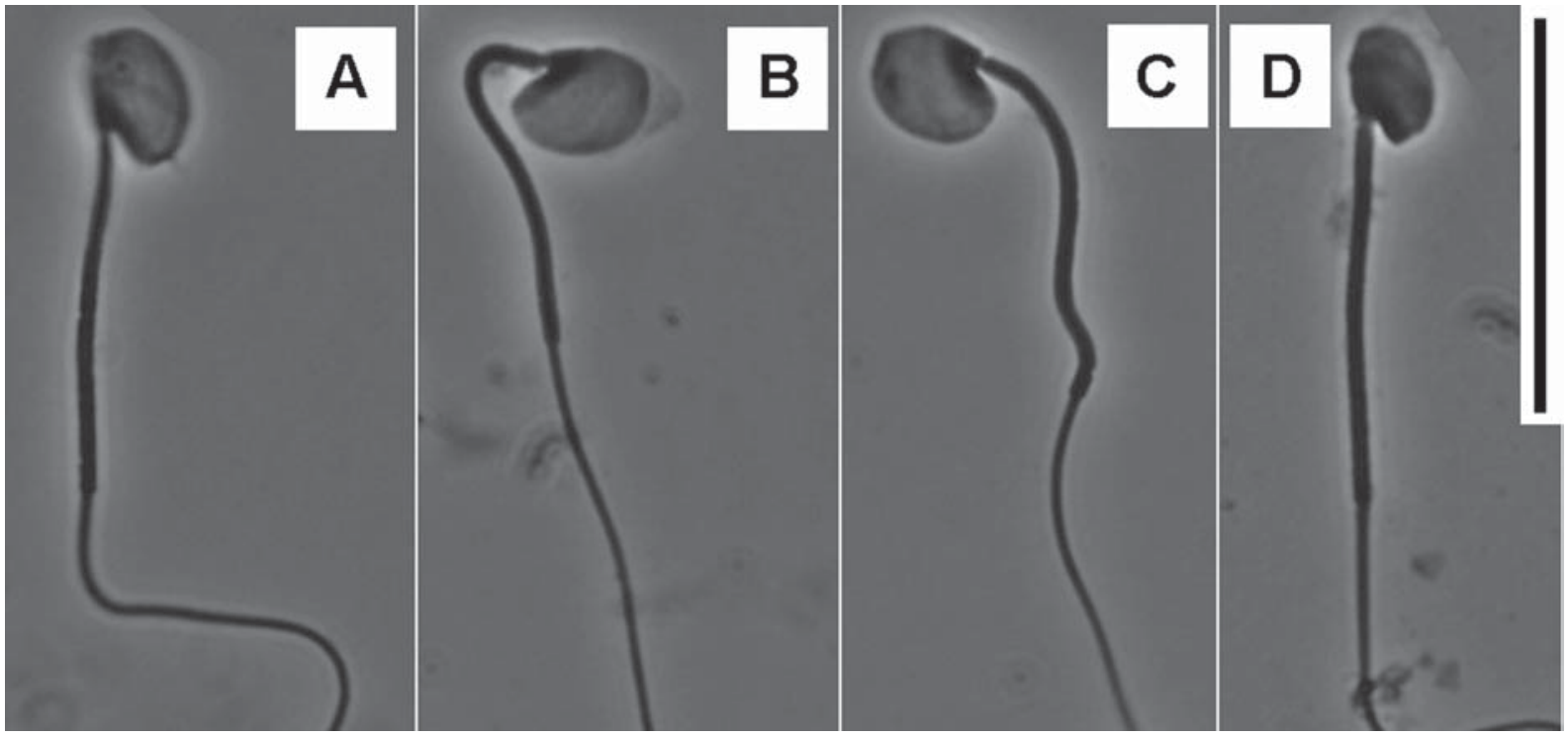

Figure 3. Spermatozoa of social voles: A - M. guentheri, B - M. h. lydius, C - M. h. strandzensis, D - M. schidlovskii. Scale bar $=20 \mathrm{~nm}$.

metric morphometrics can better identify which sperm morphology traits differ between species, for example, the protrusion or retraction of the base of the head, the degree of curvature of the hook and so on. Linear measurements do not permit to trace such features.

A trend of increase of sperm size was noted only in "guentheri" group. However, in the Kopet Dag vole the average length of a head is equal to that in $M$. $h$. strandzensis. At the same time, in the latter species the top limit of that linear character considerably exceeds that in the Kopet Dag vole (respectively 8.64 and 7.92 $\mu \kappa)$. Owing to a high variability of sperm dimensional indicators in social voles, their taxonomic value seems doubtful. The larger size of sperm in species of "guentheri" group may depend on the body size, but there is not any clear correlation between those characters.

The subgenera Sumeriomys and Microtus are well differentiated not only in a head shape and acrosome, but also in quantitative indices. The ratio of head length to its width in four species of subgenus Microtus representatives is more than $1.7(1.8-2.4)$, whereas species of the subgenus Sumeriomys - less than 1.7 (1.42- 
1.50). The relation of the sperm tail medium part length to head length in the first group is higher than 2.8 (2.8$3.2)$, but in the second - lower than $2.8(2.4-2.7)$.

Essential differences between subgenera Microtus and Sumeriomys in sperm head shape and acrosome size, combined with some differences in genital morphology were revealed (Zorenko \& Aksenova, 1989; Zorenko, 2000), do not prevent hybridization between those taxa. The hybridization between $M$. socialis and M. rossiaemeridionalis Ognev, 1924 testifies it (Kovalskaya, 2000; Kovalskaya et al., 2011). That result proved probability of hybridization between the species with different sperm morphology.

The differences in sperm morphology between populations and species evolve rapidly (Pitnick et al., 2009). The diversity in sperm design is poorly understood on the functional and evolutionary level. In invertebrates it is shown that mating behavior can considerably influence a shape of spermatozoa and morphology of genitals (Schärer et al., 2013). Direct correlation between behaviour, a structure of genitals, and spermatozoa in recent voles species is not revealed (Zorenko \& Aksenova, 1989).

The diversity in sperm design reflects the highly variable physiological and morphological environments in which sperm have to survive, function, and compete for fertilization (Eberhard, 2009). It is difficult to explain the reasons of so considerable transformations of spermatozoa in these related groups of species. Noticeable change of sperm design could be the direct result of selection or the by-product of evolutionary transformations. All changes in the structure of social voles have been directed towards strengthening the subterranean lifestyle, adaptations to digging and to harder food, and also to thermoregulation transformations. Apparently, for prevention of hybridisation between evolving species the mating stereotype, and also the chemical environment in genitals of females changed also, that probably is driven by sexual conflict of partners.

Though the mating stereotype in representatives of two subgenera, as a whole, is similar, some differences have been also noted. In social voles we record the mean number of ejaculations and intromissions' decrease in comparison with Microtus species. Individuals of $M$. arvalis and M. ilaeus Thomas, 1912 usually have an only thrust per intromission, contrary to $M$. rossiaemeridionalis and $M$. transcaspicus, that have comparatively higher number of thrusts (4-8), whereas social voles show 2-4 ones. Moreover the falling on the flank after ejaculation is usual in Microtus species but is not noted in Sumeriomys ones (Zorenko, 2013).

\section{Acknowledgements}

The work was partially supported by RFBR project no.13-04-00930-a and the "Biodiversity Program".

\section{References}

Abramson N.I. \& Lissovsky A.A. 2012. Subfamily Arvicolinae Gray, 1821 // Pavlinov I.Ya. \& Lissovsky A.A. (eds.) The Mammals of Russia: A Taxonomic and Geographic Reference. (Archives of Zoological Museum of MSU. Vol.52). Moscow: KMK Scientific Press. P.220-276.

Aksenova T.G. 1973. [A structure of accessory sex glands in some species of grey voles of genus Microtus (Rodentia, Cricetidae)] // Zoologicheskii Zhurnal. Vol.52. No.12. P.1843-1848 [in Russian, with English summary].

Aksenova T.G. 1978. [The peculiarities of spermatozoa structure and their significans in systematic of grey voles (Rodentia, Microtus)] // Strelkov P.P. (ed.). Funktsionalnaya Morphologija i Sistematika Mlekopitajushikh. (Trudy Zoologicheskogo Instituta AN SSSR. Vol.79). Leningrad. P. 91-101 [in Russian].

Baker M.A., Krutskikh A., Curry B.J., Hetherington L. \& Aitken R.J. 2005. Identification of cytochrome b5-reductase as the enzyme responsible for NADH-dependent lucigenin chemiluminescence in human spermatozoa // Biology of Reproduction. Vol.73. P.334-342.

Bierła J.B. 2006. Spermatogenesis and sperm morphology of European beaver (Caster fiber L.). Doctoral Thesis. Warsaw. Warsaw Agricultural University. $50 \mathrm{p}$.

Breed W.G. 2004. The spermatozoon of Eurasian murine rodents: its morphological diversity and evolution // Journal of Morphology. Vol.261. No.1. P.52-69.

Çolak E., Yigit N., Sözen M. \& Özkurt Ş. 1997. Distribution and taxonomic status of he genus Microtus (Mammalia: Rodentia) in Southeastern Turkey // Israel Journal of Zoology. Vol.43. No.4. P.391-396.

Cummins J.M. \& Woodall P.F. 1985. On mammalian sperm dimensions // Journal of Reproduction and Fertility. Vol.75. P.153-175.

Eberhard W.G. 2009. Postcopulatory sexual selection: Darwin's omission and its consequences // Proceedings of the National Academy of Sciences USA. Vol.106. Sup.1. P.10025-10032.

Fawcett D.W. 1975. The mammalian spermatozoon // Developmental Biology. Vol.44. No.2. P.394-436.

Golenishchev F.N. \& Abramson N.I. 2011. [New data on phylogeography of voles' subgenus Sumeriomys (Arvicolinae, Rodentia)] // Proceedings of IX Congress of Theriological Society RAS. Mammals of Russia and Adjacent Territories. 1-4 February 2011. Moscow: KMK Scientific Press. P.117 [in Russian].

Golenishchev F.N. \& Malikov V.G. 2011. [The systematics and distribution of the grey voles of the tribe Microtini (Rodentia, Arvicolinae) in the Caucasus and Asia Minor] // Proceeding of the International Conference "Biological Diversity and Conservation Problems of the Fauna of the Caucasus". 26-29 September 2011. Yerevan, Armenia. P.101-105 [in Russian, with English summary].

Golenishchev F.N., Malikov V.G., Nazari F., Vaziri A. Sh., Sablina O.V. \& Polyakov A.V. 2003. New species of vole of "guentheri" group (Rodentia, Arvicolinae, Microtus) from Iran // Russian Journal of Theriology. Vol.1. No.2. P.117-123.

Golenishchev F.N., Sablina O.V., Borodin P.M. \& Gerasi- 
mov S. 2002. Taxonomy of voles of the subgenus Sumeriomys Argyropulo, 1933 (Rodentia, Arvicolinae, Microtus) // Russian Journal of Theriology. Vol.1. No.1. P.43-55.

Gvozdetskii N.A. \& Mikhailov N.I. 1987. [Physical Geography of the USSR. The Asian Part]. Moskva: Izdatel'stvo Nauka. 448 p. [in Russian].

Kovalskaya Y.M. 2000. [Some characteristics of a hybrid between voles of the subgenera Microtus and Sumeriomys (Rodentia, Microtus)] // Agadjanian A.K. \& Orlov V.N. (eds.) Systematic and Phylogeny of the Rodents and Lagomorphs. Moscow. P.73 [in Russian].

Kovalskaya Y.M., Aksenova T.G. \& Savinetskaya L.E. 2011. [About experimental interspecific hybridization of voles genus Microtus: $M$. socialis $\times$ M.rossiaemeridionalis and $M$. arvalis obscurus] // Proceedings of IX Congress of Theriological Society RAS. Mammals of Russia and Adjacent Territories. 1-4 February 2011. Moscow: KMK Scientific Press. P.226 [in Russian].

Kryštufek B., Zorenko T. \& Buzan E. 2012. New insights into taxonomy and phylogeny of social voles inferred from mitochondrial cytochrome $b$ sequences // Mammalian Biology. Vol.77. No.3. P.178-182.

Malygin V.M. 1983. [Systematic of Common Voles]. Moscow: Izdatel'stvo Nauka. 208 p. [in Russian].

Medarde N., Muñoz-Muñoz F., López-Fuster M.J. \& Ventura J. 2013. Variational modularity at the cell level: insights from the sperm head of the house mouse // BMC Evolutionary Biology. Vol.13. P.179.

Meyer M.N., Orlov V.N. \& Skhol E.D. 1972. [Sibling species in group Microtus arvalis (Rodentia, Cricetidae)] // Zoologicheskii Zhurnal. Vol.51. No.5. P.724-738 [in Russian, with English summary].

Meyer M.N., Golenishchev F.N., Radjably S.I. \& Sablina O.V. 1996. [Voles (Subgenus Microtus Schrank) of Russia and Adjacent Territories]. (Proceeding of the Zoological Institute. Vol.232). Sankt-Petersburg: Izdatel'stvo Rossiiskoi Akademii Nauk. 319 p. [in Russian]

Miki K., Qu W., Goulding E.H, Willis W.D., Bunch D.O., Strader L.F., Perreault S.D., Eddy E.M. \& O'Brien D.A. 2004. Glyceraldehyde 3-phosphate dehydrogenase-S, a sperm specific glycolytic enzyme is required for sperm motility and male fertility // Proceedings of the National Academy of Sciences. Vol.101. No.47. P. 16501-16506.

Pitnick S., Hosken D.J. \& Birkhead T.R. 2009. Sperm morphological diversity // Birkhead T.R., Hosken D.J. \& Pitnick S. (eds.). Sperm Biology: An Evolutionary Approach. San Diego, CA: Academic Press. P.69-149.

Sánchez M.V., Bastir M. \& Roldan E.R.S. 2013. Geometric morphometrics of rodent sperm head shape // PLoS ONE. Vol.8. No.11. P.1-10.

Schärer L., Littlewood D.T.J., Waeschenbach A., Yoshida W. \& Vizoso D. 2011. Mating behavior and the evolution of sperm design // Proceedings of the National Academy of Sciences USA. Vol.108. No.4. P. 1490-1495.

Shenbrot G.I. \& Krasnov B.R. 2005: An atlas of the geographic distribution of the Arvicoline rodents of the world (Rodentia, Muridae: Arvicolinae). Sofia: Pensoft Publishers. 336 p.

Simsek N. 1981. The importance of the phallus in distinguishing Microtus socialis Pallas and Microtus guentheri Danford and Alston (Mammalia Rodentia) in Turkey // Communications Faculte Sciences de 1'Universite d'Ankara. Ser. C: Zoologie. Vol.25. P.1-10.

Yi it N. \& Çolak E. 2002. On the distribution and taxonomic status of Microtus guentheri Danford and Alston, 1880 and Microtus lydius Blackler, 1916 (Mammalia: Rodentia) in Turkey // Turkish Journal of Zoology. Vol.26. No.2. P.197-204.

Zhabin C.G., Artifeksov S.B., Nagaytsev V.M., Artifeksova M.S., Treshchenkov E.A. \& Pavlenko I.I. 2010. [Modern ideas of maturing of spermatozoa in an epididymis of testis] // Problemi Reprodukciji [Russian Journal of Human Reproduction]. No.2. P.66-73 [in Russian, with English summary].

Zorenko T.A. 2000. [Morphology of genitals and sexual behavior of social voles of the subgenus Sumeriomys (Arvicolinae, Microtus)] // Zoologicheskii Zhurnal. Vol.79. No.8. P.990-999 [in Russian, with English summary].

Zorenko T.A. 2012. [The taxonomical status of the social vole from Kopet Dagh]. Abstracts of Conference. Aktual'nie Problemi Sovremennoi Teriologii. Novosibirsk. 18-22 September 2012. P.51 [in Russian].

Zorenko T. 2013. [Social Voles of the Subgenus Sumeriomys: Systematics, Biology and Behaviour]. Saarbrücken: Palmariun Academic Publishing. 541 p. [in Russian].

Zorenko T.A. \& Aksenova T.G. 1989. [Structure of genitals, sexual behavior and problem of isolating mechanisms in voles' tribe Microtini] // Aktual'nie Problemi Zoologii. Riga: LGU. P.111-132 [in Russian].

Zorenko T. \& Motmilere I. 2005. [On what the reproductive success of males of the social vole depends?] // Proceedings of International Conference "Behaviour and Behavioral Ecology of Mammals". 4-8 October 2005. Chernogolovka, Russia. P.245-248 [in Russian].

Zorenko T., Motmillere I. \& Matjuskova N. 2005. Does the feeding with mushroom shiitake increase reproductive capacity of mammals? // Abstracts of the 3-rd International Symposium "Physiological Bases for Increasing the Productivity of Mammals Introduced in Zooculture". 27-29 September 2005. Petrozavodsk. P.72-75.

Zykov A.E. \& Zagorodnyuk I.V. 1988. [On the systematic position of voles (Mammalia, Rodentia) from Kopet Dagh] // Vestnik Zoologii. Vol.5. P.46-52 [in Russian, with English summary]. 